See discussions, stats, and author profiles for this publication at: https://www.researchgate.net/publication/325737090

First record of the alien leech Myzobdella lugubris Leidy, 1851 (Hirudinea, Piscicolidae) in the Palearctic

Article in Limnetica · May 2018

DOI: $10.23818 /$ limn. 37.25

CITATIONS

0

5 authors, including:

Mirko Liuzzo

Università Ca' Foscari Venezia

2 PUBLICATIONS OCITATIONS

SEE PROFILE

Elena Bel

Université de Montréal

6 PUBlications 120 CITATIONS

SEE PROFILE

Some of the authors of this publication are also working on these related projects:

Ecobiology of shark species in the Mediterranean View project

Project Nuove intuizioni sul microbioma intestinale nelle tartarughe marine Caretta Caretta arenata sulla costa del Mediterraneo View project
READS

202

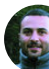

Università del Salento

47 PUBLICATIONS 243 CITATIONS

SEE PROFILE

Università degli Studi di Palermo

198 PUBLICATIONS 1,863 CITATIONS

SEE PROFILE
Marco Arculeo 


\title{
First record of the alien leech Myzobdella lugubris Leidy, 1851 (Hirudinea, Piscicolidae) in the Palearctic
}

\author{
M. Liuzzo ${ }^{1}$, G. Alfonso ${ }^{2}$, E. Beli2,3, M. Arculeo ${ }^{1}$ and F. Marrone ${ }^{1, *}$ \\ ${ }^{1}$ Dipartimento di Scienze e Tecnologie Biologiche, Chimiche e Farmaceutiche, Sezione di Biologia animale, \\ University of Palermo, via Archirafi 18 - 90123 Palermo, Italy. \\ 2 Di.S.Te.B.A. University of Salento, sp Lecce-Monteroni - 73100 Lecce, Italy. \\ 3 Département de sciences biologiques, Université de Montréal C.P. 6128, Succursale Centre-ville, Montréal, \\ Québec H3C 3J7, Canada. \\ * Corresponding author: federico.marrone@unipa.it
}

Received: 22/01/18 Accepted: 07/05/18

\begin{abstract}
First record of the alien leech Myzobdella lugubris Leidy, 1851 (Hirudinea, Piscicolidae) in the Palearctic

In this study, we report the occurrence of the Nearctic leech Myzobdella lugubris in a brackish water body of the Riserva Naturale dello Stato "Le Cesine" (Apulia, Italy). Two specimens of the species were collected in October 2016 from the neck and the forelimbs of a European pond turtle, Emys orbicularis hellenica, and identified both based on morphology and molecular sequence data. In its native range, $M$. lugubris is known to be a host and vector of bacteria and viruses, among which some serious fish pathogens. In light of the possible noxious ecological effects exerted through pathogen spillover on autochthonous vertebrates, the distribution of the species and its possible role as a vector of pathogens in the invaded area should be urgently monitored.
\end{abstract}

Key words: Emys orbicularis hellenica, R.N.S. "Le Cesine”, Biological invasions, pathogen spillover

\section{RESUMEN}

Primer registro de la especie invasora Myzobdella lugubris Leidy, 1851 (Hirudinea, Piscicolidae) en el Paleártico

En este estudio reportamos la aparición de la sanguijuela Neartica Myzobdella lugubris en un cuerpo de agua salobre de la reserva natural Riserva Naturale dello Stato "Le Cesine" (Apulia, Italy). Dos especimenes de la especie fueren recolectados en el cuello y las extremidades anteriores de una tortuga de estanque europea Emys orbicularis hellenica en Octubre del 2016. La identificación de los dos especimenes fue basada en datos morfológicos y de secuenciación molecular. En su distribución natural, M. lugubris es conocida por ser huésped y vector de bacterias y virus, de los cuales algunos son patógenos de gravedad en peces. En vista de los posibles efectos nocivos, que ejercen sobre las poblaciones autóctonas de vertebrados a través de la propagación de patógenos, es urgente monitorear la distribución de la especie y su posible rol como vector de patógenos en las áreas invadidas.

Palabras clave: Emys orbicularis hellenica, R.N.S. “Le Cesine”, Invasión biológica, propagación de patógenos 


\section{INTRODUCTION}

Myzobdella lugubris Leidy, 1851 (Hirudinea: Piscicolidae) is a common euryhaline leech occurring throughout North American fresh and brackish waters (Sawyer \& Shelley, 1976; Klemm, 1985) (Fig. 1). The wide distribution of the species seems to be related to its salinity tolerance: $M$. lugubris has been collected in water bodies with salinity levels ranging from 0 to $26 \%$ (Sawyer et al., 1975). Cocoons are able to hatch at salinity values comprised between $13 \%$ and $28 \%$ (Oren, 1981). During most of the year, $M$. lugubris is parasitic on a piscine host (usually belonging to the families Ictaluridae, Mugilidae, Paralichthyidae or Fundulidae), but it leaves the fish host to lay its cocoons on decapods (Daniels et al., 1975; Saglam et al., 2018). In brackish areas, the cocoons are usually deposited on the blue crab (Callinectes sapidus Rathbun, 1896) (Daniels et al., 1975).

Myzobdella lugubris is also known to be a host of bacteria (e.g. Flavobacterium psychrophilum (Bernardet \& Grimont 1989)) (Schulz \& Faisal, 2010) and viruses (Viral Hemorrhagic Septicemia virus) (Faisal \& Schulz, 2009). The bacterium $F$. psychrophilum is a fish pathogen that causes "Bacterial Cold Water Disease" (Schulz et al.,

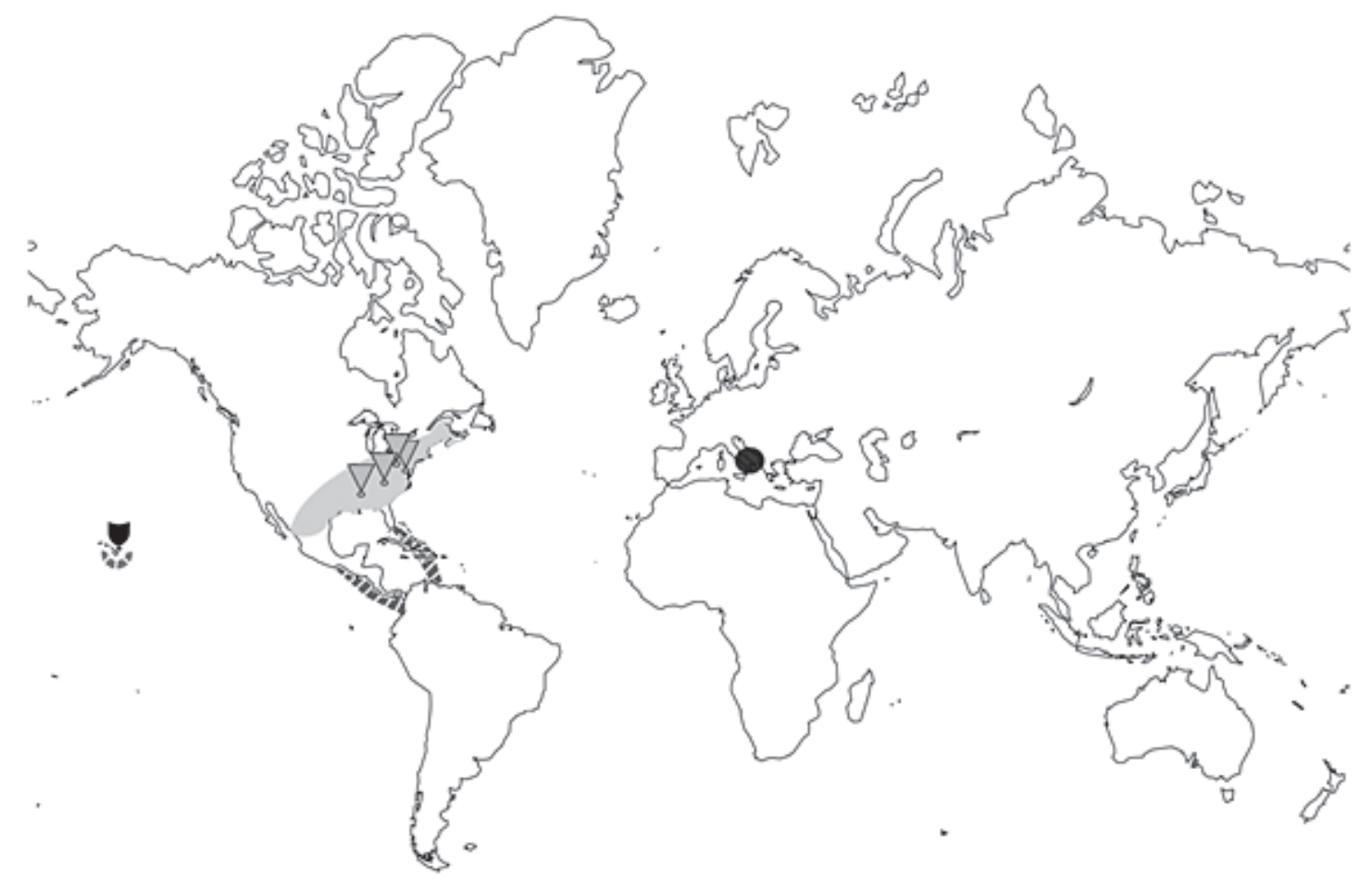

Samples of authochonous populations

Sample of allochthonous population

New Paleartic allochthonous population

믈 Non-native range of the species

Native range of the species

Figure 1. Geographic distribution of Myzobdella lugubris and origin of the studied samples. The symbols on the map indicate the samples included in the molecular analyses. The circle represents the Palearctic locality where Myzobdella specimens were collected. The grey dotted area shows the non-native distribution range of the species whereas the grey full area represents its native distribution range. Distribución geográfica y origen de las muestras estudiadas de Myzobdella lugubris. Los símbolos en el mapa indican las muestras que fueron incluidas en el análisis molecular. El círculo representa la localidad Peleártica en donde los especímenes de Myzobdella fueron colectados. El área punteada en gris indica el rango no nativo de distribución de las especies, mientras el área totalmente gris representa su rango de distribución nativo. 
2010), although it is currently unknown whether $M$. lugubris can actually transmit the virus to fish hosts (Faisal \& Schulz, 2009). In the area of Lake Erie (Michigan, USA), M. lugubris dominates the leech community and heavily parasitizes the channel catfish Ictalurus punctatus (Rafinesque, 1818) and the freshwater drum Aplodinotus grunniens Rafinesque, 1818 (Schulz \& Faisal, 2010).

Although the species successfully invaded several regions of North and Central America (e.g. Font, 2003), to date, no records of the species out of the Nearctic region are available (Neubert \& Nesemann, 1999; Minelli, 2005; Saglam et al., 2018).

In the frame of the sampling activities aimed at investigating the phylogeography of the glossiphoniid leech Placobdella costata (Fr. Müller, 1846) in the western Palearctic, two leech specimens ascribable to the Nearctic piscicolid genus Myzobdella Leidy, 1851 were collected on a turtle host in southern Italy. These specimens were thus studied in order to identify them at the species level and to single out their possible origin and dispersal vector.

\section{MATERIAL AND METHODS}

Sampling was carried out in southern Italy Riserva Naturale dello Stato Oasi WWF "Le Cesine" (Vernole, LE). The study site $\left(40^{\circ} 21^{\prime} 12^{\prime \prime}\right.$ $\left.\mathrm{N}, 18^{\circ} 20^{\prime} 31^{\prime \prime} \mathrm{E}\right)$ is a canal in a wide coastal wetland characterized by the presence of different habitats: canals, permanent and temporary water bodies, swamps and brackish areas.

The sampling, aimed at censing the local population of the glossiphoniid leech Placobdella costata, was carried out in October 2016 with the permission of the managing authority. A single European pond turtle, Emys orbicularis hellenica (Valenciennes, 1832) was captured with a baited funnel trap left overnight in the sampling site. Two leech specimens were found on the neck and forelimb of this pond turtle and were collected and fixed in situ in $95 \%$ ethanol. They were later identified as Myzobdella lugubris based on the morphological key of Moore (1946) and the description provided by Saglam et al. (2018); one of the collected specimens was deposited at the Museo di Storia Naturale, Sezione di Zoologia
"La Specola", University of Firenze, Italy (Registration number: MZUF1929). One leech was also analyzed genetically by amplifying and sequencing a 540-bp-long fragment of the cytochrome oxidase subunit I mtDNA gene (COI), the DNA barcode, a marker which is widely used in Hirudinea systematics (e.g. Siddall et al., 2005; Oceguera-Figueroa et al., 2010; Marrone et al., 2016; Saglam et al., 2018). DNA extraction was carried out with BIORON Ron's Tissue DNA mini kit following the manufacturer's protocol. A partial sequence of the mitochondrial gene COI was amplified using the primers LCO1490 and HCO2198 described by Folmer et al. (1994).

PCR mix consisted of $2.5 \mu \mathrm{l}$ of BIORON 10x ammonium buffer, $0.4 \mu \mathrm{l}$ of dNTP at $10 \mathrm{mM}, 0.5$ $\mu 1$ of each $0.5 \mu \mathrm{l}$ primer, $0.3 \mu \mathrm{l}$ of BIORON DSF Taq enzyme, $1.5 \mu \mathrm{l}$ of DNA template and $19.3 \mu \mathrm{l}$ of double-distilled water, for a total reaction volume of $25 \mu \mathrm{l}$. The amplification consisted of an initial denaturation step of $94{ }^{\circ} \mathrm{C}$ for $5 \mathrm{~min}$ followed by 35 cycles of $94{ }^{\circ} \mathrm{C}$ for $45 \mathrm{~s}, 45^{\circ} \mathrm{C}$ for $45 \mathrm{~s}$ and $72^{\circ} \mathrm{C}$ for $60 \mathrm{~s}$, followed by a final extension at $72{ }^{\circ} \mathrm{C}$ for $5 \mathrm{~min}$.

The PCR product was checked on a $2 \%$ agarose gel, purified using the Exo-SAP-IT kit (Affymetrix USB) and sequenced by Macrogen Inc. (Spain) with an ABI 3130xl (Applied Biosystems) sequencer with the same primers used for PCR amplification. The chromatogram was imported and edited with Chromas Lite 2.6.4 (Technelysium Pty Ltd, South Brisbane, Australia); MEGA7 (Kumar et al., 2016) was used to translate the novel COI sequence to amino acids in order to check for the possible presence of frameshifts or stop codons, which would indicate the presence of sequencing errors or pseudogenes. The novel sequence was deposited in GenBank under the Accession Number MG820612.

All the Myzobdella sequences available on GenBank, and a single sequence of the piscicolid leech Piscicola geometra (Linnaeus, 1761) to be used as outgroup, were downloaded and included in the molecular analysis (see figure 2 for their Accession Numbers).

Novel and published GenBank sequences were aligned with ClustalX (Thompson et al., 1997). Bayesian inference (BI) of the phylogenet- 
ic analysis was then performed as implemented in MrBayes 3.2.6 (Ronquist et al., 2012). The analysis was performed using a Generalized Time Reversible model of sequence evolution with a proportion of invariable sites (GTR $+\mathrm{R})$, as selected by the Akaike information criterion in jModelTest 2.1.9 (Darriba et al., 2012). Node supports were evaluated by their posterior proba- bilities. The BI analysis was performed with two independent runs of 1000000 generations and four Markov chains using default heating values. Trees and parameter values were sampled every 100 generations resulting in 10000 saved trees per analysis. An initial fraction of 2000 trees (20\%) was conservatively discarded as 'burn-in'. For all analyses, standard deviation of split frequencies

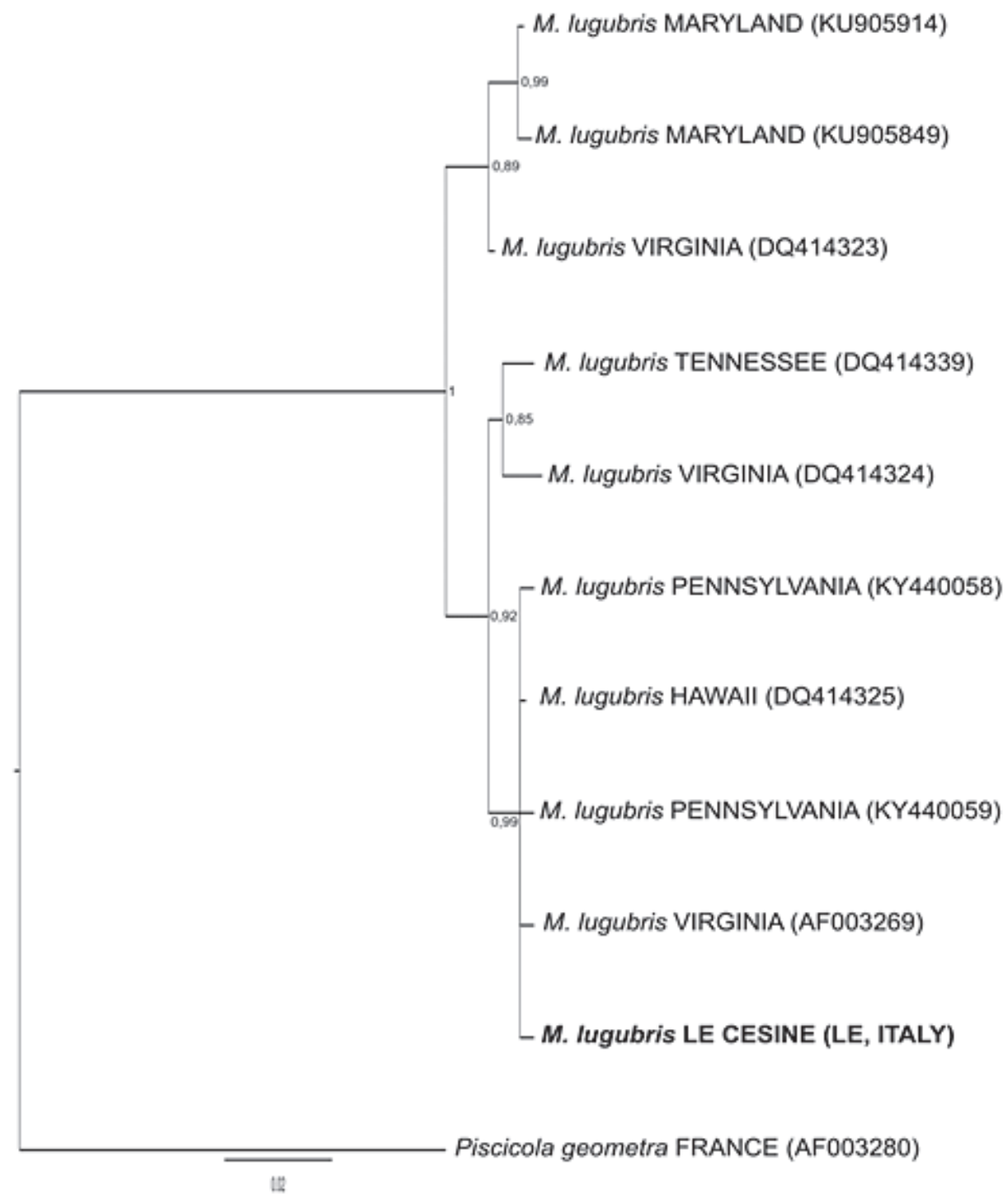

Figure 2. Bayesian phylogram based on a 540-bp-long fragment of the mtDNA gene for the cytochrome oxidase subunit I. Node support is reported as nodal posterior probabilities. The accession numbers of the sequences derived from GenBank are shown in brackets. Filograma bayesiano basado en un fragmento de 540-bp-long del gen mtDNA del citocromo oxidasa subunidad I. El soporte al nodo es reportado como probabilidad nodal posterior. Los números de acceso de las secuencias derivados de GenBank están indicados entre paréntesis. 
reached values lower than 0.0078 , and values of the potential scale reduction factor (PSRF) were between 1.000 and 1.006 for all parameters, thus indicating convergence of the runs.

\section{RESULTS}

Collected leeches were identified as Myzobdella lugubris on a morphological basis. The sequencing of the chosen marker and its comparison with the publicly available sequences confirmed its univocal identification, with the Myzobdella sequence from "Le Cesine" clustering within a $M$. lugubris clade including samples from Pennsylvania, the Hawaii and Virginia, i.e. both from native and non-native parts of its distribution range, in the BI tree (Fig. 2).

The topology of the phylogenetic tree based on BI thus confirmed the morphology-based identification of the leech collected in "Le Cesine" as Myzobdella lugubris.

\section{DISCUSSION}

Biological invasions are nowadays unanimously recognized as one of the main threats to the conservation of biological diversity worldwide, and inland waters are known to be highly vulnerable to either inadvertent or deliberate introductions of species and to their subsequent spread (Gherardi et al., 2008). Several alien species of North American origin have successfully invaded southern Italian inland and coastal waters, often threatening the autochthonous biota (e.g. Gennaio et al., 2006; Cianfanelli et al., 2007; Gravili et al., 2010; Marrone et al., 2011; Mancinelli et al., 2013; Bianco, 2014; Marrone \& Naselli-Flores, 2015; Vecchioni et al., 2017; Cilenti et al., 2017, and references therein).

This work reports the first evidence of the presence of the leech Myzobdella lugubris in the whole Palearctic: to date, no Myzobdella species were known to occur in this biogeographical region (Peckarsky et al., 1990; Hoffman, 1999, Fofonoff et al., 2018) (see Fig. 1). The anthropogenic introduction of this leech out of its native range was possibly facilitated by its robust mechanisms for natural or anthropogenic passive dispersal (Saglam et al., 2018). In the
Mediterranean area, the arrival of this Piscicolidae is possibly related to the commercial import of blue crabs (Callinectes sapidus) from the eastern U.S.A. and the Gulf of Mexico (Morado, 2007), facilitated by the strong adherence of Myzobdella cocoons to crustacean exoskeletons (Saglam et al., 2018). It is possibly not by chance that the site where M. lugubris was observed is located just $13 \mathrm{~km}$ from the Aquatina lagoon, an Apulian site where C. sapidus specimens were found to be co-occurring with Hematodinium sp., a dinoflagellate parasite of crustaceans including Callinectes sapidus, typical of the Atlantic coasts (Mancinelli et al., 2013).

Myzobdella lugubris is a potentially noxious taxon, associated with epidemic oral ulceration in the largemouth bass (Micropterus salmoides Lacèpède, 1802) (Noga et al., 1990) and with the bacterium Flavobacterium psychrophilum, which is the causative agent of the "Bacterial Cold-Water Disease" and of the "Rainbow Trout Fry Syndrome". Both these diseases cause high mortality in salmonids and increase their susceptibility to other diseases (Nematollahi et al., 2003). M. lugubris is also known to be a vector of the Viral Hemorrhagic Septicemia virus (VHSV), which causes high mortality among fish communities.

The present report is the first evidence of Myzobdella lugubris occurring on a reptile; it remains unclear, however, if the two specimens were actually feeding on the pond turtle, or were rather there for cocoon deposition or other non-trophic reasons, as demonstrated in the glossiphoniid genus Helobdella (Marrone et al., 2016). However, analogously to what was stressed for the system "Haemogregarina stepanowi - Placobdella costata - Emys trinacris" by Arizza et al. (2016), the possible presence of pathogen spillover related to $M$. lugubris on the vertebrates occurring in "Le Cesine" and neighboring areas must be monitored.

The finding of two adult Myzobdella lugubris specimens on the single pond turtle captured suggests that a significant population of the species might be present in the study area, but further investigations are needed to test this hypothesis, including sampling of fishes, decapods and other potential hosts along the Apulian coasts. 


\section{ACKNOWLEDGEMENTS}

Giuseppe De Matteis, responsible of the "Riserva Naturale dello Stato Oasi WWF Le Cesine", is kindly acknowledged for having provided the permit to sample E. orbicularis and associated leeches in the R.N.S. "Le Cesine". Mario Congedo (Corpo Forestale dello Stato, San Cataldo, LE) and Rita Scardino (University of Palermo, Italy) provided useful suggestions for field activities. Dr. Elisabetta Oddo (University of Palermo, Italy) is acknowledged for the linguistic revision of a first draft of the manuscript.

\section{REFERENCES}

ARIZZA, V., F. SACCO, D. RUSSO, R. SCARDINO, M. ARCULEO, M. VAMBERGER \& F. MARRONE. 2016. The good, the bad and the ugly: Emys trinacris, Placobdella costata and Haemogregarina stepanowi in Sicily (Testudines, Annelida and Apicomplexa). Folia parasitologica, 63: 029. DOI: 10.14411/fp.2016.029

BIANCO, P.G. 2014. An update on the status of native and exotic freshwater fishes of Italy. Journal of Applied Ichthyology, 30: 62-77. DOI: $10.1111 /$ jai.12291

CIANFANELLI, S., E. LORI \& M. BODON. 2007. Non-indigenous freshwater molluscs and their distribution in Italy. In: Biological invaders in inland waters: profiles, distribution, and threats. F. Gherardi (ed.): 103-121. Springer, Dordrecht. DOI: 10.1007/978-1-4020-6029-8_5

CILENTI, L., G. ALFONSO, M. GARGIULO, F.S. CHETTA, A. LIPAROTO, R. D'ADAMO \& G. MANCINELLI. 2017. First records of the crayfish Procambarus clarkii (Girard, 1852) (Decapoda, Cambaridae) in Lake Varano and in the Salento Peninsula (Puglia region, SE Italy), with review of the current status in southern Italy. BioInvasions Records, 6: 153-158. DOI: 10.3391/bir.2017.6.2.11

DANIELS, B.A. \& R.T. SAWYER. 1975. The biology of the leech Myzobdella lugubris infesting blue crabs and catfish. Biolological Bullettin, 148: 193-198. DOI: 10.2307/1540542

DARRIBA, D., G.L. TABOADA, R. DOALLO \& D. POSADA. 2012. JModelTest 2: more models, new heuristics and parallel computing. Nature Methods, 9: 772. DOI: 10.1038/ nmeth.2109

FAISAL, M. \& C.A. SCHULZ. 2009. Detection of Viral Hemorrhagic Septicemia virus (VHSV) from the leech Myzobdella lugubris Leidy 1851. Parasites \& Vectors, 2: 45. DOI: 10.1186/1756-3305-2-45

FOFONOFF, P.W., G.M. RUIZ, B. STEVES, C. SIMKANIN \& J.T. CARLTON. 2018. National Exotic Marine and Estuarine Species Information System. http://invasions.si.edu/ nemesis/. Access Date: 17-Jan -2018

FOLMER, O., M. BLACK, W. HOEH, R. LUTZ \& R. VRIJENHOEK. 1994. DNA primers for amplification of mitochondrial cytochrome c oxidase subunit I from diverse metazoan invertebrates. Molecular Marine Biology and Biotechnology, 3: 294-299.

FONT, W.F. 2003. The Global Spread of Parasites: what do Hawaiian streams tell us? BioScience, 53: 1061-1067. DOI: 10.1641/ 0006-3568(2003)053[1061:TGSOPW]2.0.CO;2 GENNAIO, R., G. SCORDELLA \& M. PASTORE. 2006. On the occurrence of the blue crab Callinectes sapidus (Rathbun, 1896 Crustacea, Brachyura) in the Ugento ponds area (Lecce, Italy). Thalassia Salentina, 29: 29-39.

GHERARDI, F., S. BERTOLINO, M. BODON, S. CASELLATO, S. CIANFANELLI, M. FERRAGUTI, E. LORI, G. MURA, A. NOCITA, N. RICCARDI, G. ROSSETTI, E. ROTA, R. SCALERA, S. ZERUNIAN \& E. TRICARICO. 2008. Animal xenodiversity in Italian inland waters: distribution, modes of arrival, and pathways. Biological Invasions, 10: 435-454. DOI: 10.1007/s10530-007-9142-9

GRAVILI, C., G. BELMONTE, E. CECERE, F. DENITTO, A. GIANGRANDE, P. GUIDETTI, C. LONGO, F. MASTROTOTARO, S. MOSCATELLO, A. PETROCELLI, S. PIRAINO, A. TERLIZZI \& F. BOERO. 2010. Nonindigenous species along the Apulian coast, Italy. Chemistry and Ecology, 26: 121-142. DOI: 10.1080/02757541003627654

HOFFMAN, G.L. 1999. Parasites of North American Freshwater Fishes, Second Edition. Cornell University Publishing, NY. USA. 
KLEMM, D.J., 1985. Freshwater leeches (Annelida: Hirudinea). In:. A guide to freshwater Annelida (Polychaeta, naidid and tubificid Oligochaeta, and Hirudinea) of North America. Klemm DJ (ed). Kendall Hunt Publishing Co. pp. 198

KUMAR, S., STECHER, G. \& K. TAMURA. 2016. MEGA7: Molecular Evolutionary Genetics Analysis version 7.0 for bigger datasets. Molecular Biology and Evolution, 33: 1870-1874. DOI: 10.1093/molbev/msw054

MANCINELLI, G., L. CARROZZO, G. MARINI, P. PAGLIARA \& M. PINNA. 2013. The co-occurrence of Callinectes sapidus Rathbun, 1896 (Brachyura: Portunidae) and the parasitic dinoflagellate Hematodinium sp. (Dinoflagellata: Syndinidae) in two transitional water ecosystems of the Apulia coastline (South-Italy). Transitional Waters Bulletin, 7: 32-42. DOI: 10.1285/i1825229Xv7n1p32

MARRONE, F., LO BRUTTO, S. \& M. ARCULEO. 2011. Cryptic invasion in Southern Europe: the case of Ferrissia fragilis (Pulmonata: Ancylidae) Mediterranean populations. Biologia, 66: 484-490. DOI: 10.2478/s11756011-0044-z

MARRONE, F. \& L. NASELLI-FLORES. 2015. A review on the animal xenodiversity in Sicilian inland waters (Italy). Advances in Oceanography and Limnology, 6: 2-12. DOI: 10.4081/aiol.2015.5451

MARRONE, F., F. SACCO, C. KEHLMAIER, V. ARIZZA \& M. ARCULEO. 2016. Some like it cold: the glossiphoniid parasites of the Sicilian endemic pond turtle Emys trinacris (Testudines, Emydidae), an example of 'parasite inertia'? Journal of Zoological Systematics and Evolutionary Research, 54: 60-66. DOI: $10.1111 /$ jzs. 12117

MINELLI, A. 2005. Annelida Hirudinea. In: Checklist e Distribuzione Della Fauna Italiana. Ruffo S. \& F. Stoch (eds),. Memorie del Museo Civico di Storia Naturale di Verona, $2^{\circ}$ serie, Sezione Scienze della Vita, 16: 77-78.

MOORE, J.P. 1946. The anatomy and systematic position of Myzobdella lugubris Leidy (HIRUDINEA). The Academy of natural Sciences Of Philadelphia, PA. USA.

MORADO, J.F. 2007. Bitter crab syndrome: a major player in the global theater of marine crustacean disease. AFSC Quarterly Report, July-September, 1-6.

NEMATOLLAHI, A., A. DECOSTERE, F. PASMANS \& F. HAESEBROUCK. 2003. Flavobacterium psychrophilum infections in salmonid fish. Journal of Fish Diseases, 26: 563-574.

NEUBERT, E. \& H. NESEMANN. 1999. Annelida, Clitellata: Branchiobdellida, Acanthobdellea, Hirudinea. Süßwasserfauna von Mitteleuropa 6/2. Heidelberg: Spektrum

NOGA, E.J., BULLIS R.A. \& G.C. MILLER. 1990. Epidemic Oral Ulceration in Largemouth Bass (Micropterus salmoides) associated with the Leech Myzobdella lugubris. Journal of Wildlife Diseases, 26: 132-134. DOI: 10.7589/0090-3558-26.1.132

OCEGUERA-FIGUEROA, A., V. LEON-REGAGNON \& M.E. SIDDALL. 2010. DNA barcoding reveals Mexican diversity within the freshwater leech genus Helobdella (Annelida: Glossiphoniidae). Mitochondrial DNA, 21: 24-29. DOI: 10.3109/19401736.2010.527965

OREN, O.H. 1981. Aquaculture of grey Mullets. Cambridge University Press, London, UK.

PECKARSKY, B.L., P.R. FRAISSINET, M.A. PENTON \& D.J. CONKLIN. 1990. Freshwater Macroinvertebrates of Northeastern North America. Cornell University Publishing, NY. U.S.A.

RONQUIST, F., M.P. TESLENKO, D.L. VAN DER MARK, A. AYRES, S. DARLING, B. HEOHNA, L. LARGET, M.A. SUCHARD \& J.P. HUELSENBECK. 2012. MrBayes 3.2: efficient Bayesian phylogenetic inference and model choice across a large model space. Systematic Biology, 61: 539-542. DOI: 10.1093/sysbio/sys029

SAGLAM, N., R. SAUNDERS, S.A. LANG \& D.H. SHAIN. 2018. Phylogeny and cocoon production in the parasitic leech Myzobdella lugubris Leidy, 1851 (Hirudinidae, Piscicolidae). Acta Parasitologica, 63: 15-26. DOI: 10.1515/ap-2018-0002

SAWYER, R.T. \& R.M. SHELLEY. 1976. New records and species of leeches (Annelida: Hirudinea) from North and South Carolina. Journal of Natural History, 10: 65-97. DOI: 
10.1080/00222937600770061

SAWYER, R.T., A.R. LAWLER \& R.M. OVERS-

RTEET. 1975. Marine leeches of the eastern United States and the Gulf of Mexico with a key to the species. Journal of Natural History, 9: 633-667. DOI: 10.1080/00222937500770531

SCHULZ, C. \& M. FAISAL. 2010. The bacterial community associated with the leech Myzobdella lugubris Leidy, 1851 (Hirudinea: Piscicolidae) from lake Erie e Michigan, USA. Parasite, 17: 113-12. DOI: 10.1051/parasite/ 2010172113

SIDDALL, M.E., R.B. BUDINOFF \& E. BORDA. 2005. Phylogenetic evaluation of systematics and biogeography of the leech family Glossiphoniidae. Invertebrate Systematics, 19: 105-112. DOI: 10.1071/IS04034

THOMPSON, J.D., GIBSON, T.J., PLEWNIAK, F., JEANMOUGIN, F. \& D.G. HIGGINS. 1997. The ClustalX windows interface: flexible strategies for multiple sequence alignment aided by quality analysis tools. Nucleic Acids Research, 25: 4876-4882.

VECCHIONI, L., F. MARRONE, M. ARCULEO \& V. ARIZZA. 2017. Are there autochthonous Ferrissia (Mollusca: Planorbidae) in the Palaearctic? Molecular evidence of a widespread North American invasion of the Old World. The European Zoological Journal, 84: 411-419. DOI: $10.1080 / 24750263.2017 .1350759$ 